\title{
Deletion 18p Syndrome
}

National Cancer Institute

\section{Source}

National Cancer Institute. Deletion 18p Syndrome. NCI Thesaurus. Code C84521.

A rare genetic syndrome characterized by the deletion of the short arm of chromosome

18. It is associated with mental and growth retardation, prominent ears and ptosis. 